\title{
36. ORGANIC CARBON ISOTOPIC COMPOSITION IN CRETACEOUS SEDIMENTS, ANGOLA BASIN, SOUTHEASTERN ATLANTIC, DEEP SEA DRILLING PROJECT SITE 530 ${ }^{1}$
}

\author{
Masato Nohara, Geological Survey of Japan, Ibaraki 305 Japan \\ Toshio Ishizuka, Ocean Research Institute, University of Tokyo, Nakano 164, Japan \\ and \\ Joris M. Gieskes, Scripps Institution of Oceanography, La Jolla, California
}

\begin{abstract}
Cretaceous sediments from DSDP Site 530 have been analyzed for organic carbon isotopic composition. The $\delta^{13} \mathrm{C}$ values in the sediments decrease from $-22.7 \%$ to $-27.5 \%$ in the following order: light-olive green mudstone/claystone, dark brown-red mudstone/siltstone/claystone, and black shale. This large range is primarily the result of variation in the relative amounts of terrestrial organic carbon superimposed on that derived from marine organisms.

The black shales have an average $\delta^{13} \mathrm{C}$ value of $-25.9 \%$ (range is from $-23.7 \%$ to $-27.5 \%$ ). These values indicate that they originated primarily in terrigenous organic materials.

The average $\delta^{13} \mathrm{C}$ value present throughout the Cretaceous suggests that a large amount of terrestrial organic matter was supplied into this paleoenvironment, except during the Campanian, when an average $\delta^{13} \mathrm{C}$ of $-23.9 \%$ is found near the marine end of the range.
\end{abstract}

\section{INTRODUCTION}

A primary objective at Site 530 was to investigate the paleoenvironmental history of the South Atlantic, particularly of the Cretaceous black shales in the Angola Basin. Cretaceous black shales have been encountered in Atlantic Ocean sediments from various drill sites. Some of the areas were anoxic basins with high sedimentation rates and large terrigenous components of organic matter (Foresman, 1978; Simoneit, 1978, 1979; Summerhayes, 1981). Therefore, it is of interest to clarify whether black shales originated from marine or terrestrial organic matter.

Stable carbon isotope analyses were made on light-olive green to dark brown-red mudstone/siltstone/claystone and black shales from Site 530 (Cores 50 through 105) of Leg 75 in the Angola Basin. Site 530 was drilled at the southeastern corner of the Angola Basin, about $20 \mathrm{~km}$ north of the Walvis escarpment, near the eastern end of Walvis Ridge $\left(19^{\circ} 11,26^{\prime} \mathrm{S}, 9^{\circ} 23,15^{\prime} \mathrm{E}\right.$; sub-bottom depth, $4629 \mathrm{~m}$ ) (See Fig. 1.)

\section{ANALYTICAL PROCEDURE}

Organic carbon samples were treated with $0.1 \mathrm{~N} \mathrm{HCl}$ to eliminate any contribution from inorganic carbon. An aliquot of the dried residue was combusted at about $1000^{\circ} \mathrm{C}$ for 120 minutes in the presence of copper oxide and oxygen as outlined by Craig (1953). The purified $\mathrm{CO}_{2}$ was analyzed with a Varian MAT 250 mass spectrometer. The results are reported relative to the Chicago PDB standard in terms of $\delta^{13} \mathrm{C}$, defined as;

$$
\delta^{13} \mathrm{C}(\%)=\left[\frac{{ }^{13} \mathrm{C} /{ }^{12} \mathrm{C} \text {-sample }}{{ }^{13} \mathrm{C} /{ }^{12} \mathrm{C} \text {-standard }}-1\right] \times 1000
$$

\footnotetext{
${ }^{1}$ Hay, W. W., Sibuet, J.-C., et al., Init. Repts. DSDP, 75: Washington (U.S. Govt.
}

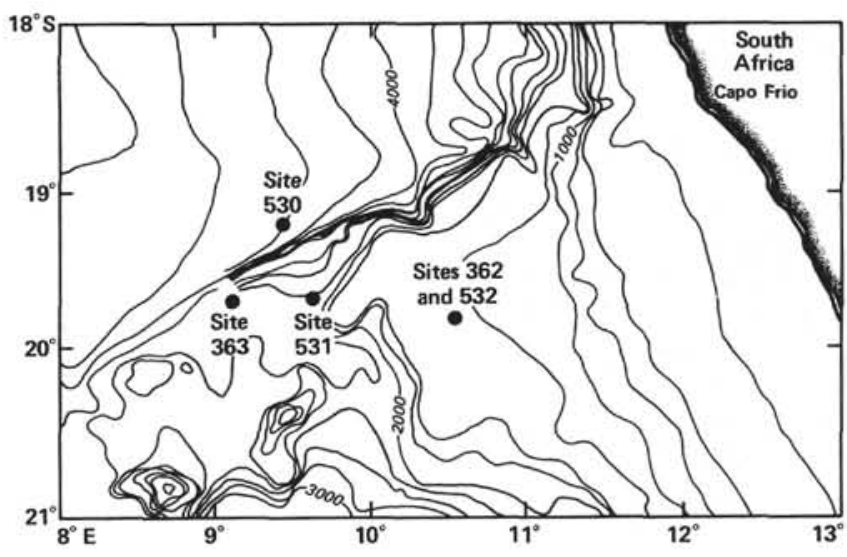

Figure 1. Location of Leg 75 sites in the Angola Basin.

The standard deviation between duplicate runs is better than $\pm 0.2 \%$. Reproducibility of the measurement on a sample is better than $\pm 0.1 \%$.

\section{RESULTS AND DISCUSSION}

The sample descriptions and analytical results are given in Table 1 with total organic carbon contents.

In general, organic carbon isotope compositions are significantly more depleted in ${ }^{13} \mathrm{C}$ in all the Cretaceous sediments, particularly in Sections 87-1 through 4; 96,CC; 99,CC; 101-4; 102-2 through 3 ; and 105-2. Sections 74-2; 85-5; 86-4; and 88-3 exhibit a slight enrichment in $\delta^{13} \mathrm{C}$, ranging from $-22.7 \%$ to $-23.9 \%$. The least depleted $\delta^{13} \mathrm{C}$ value is found in Core 74 , Section 2 , which has low total organic carbon $(0.11 \%)$ and $38 \%$ carbonate contents. Detailed analyses of $\delta^{13} \mathrm{C}$ were carried out on Sections 87-1 to 87-4. The lithology varies with increasing depth as follows: light green claystone with light gray siltstone, black shale, red claystone with thin greenish siltstone, and again black shale. The light- 
Table 1. Organic carbon isotopic composition in Cretaceous sediments at Site 530, Leg 75.

\begin{tabular}{|c|c|c|c|c|}
\hline $\begin{array}{l}\text { Core-Section } \\
\text { (interval in } \mathrm{cm} \text { ) }\end{array}$ & $\begin{array}{c}\text { Total } \\
\text { organic } \\
\text { carbon }(\%)\end{array}$ & $\begin{array}{l}\delta^{13} \mathrm{C} \\
\left(\%,{ }_{0}\right)\end{array}$ & $\mathrm{Age}^{\mathrm{a}}$ & Lithology \\
\hline $50-4,91-92$ & 0.06 & -25.3 & Maestrichtian & Green mudstone \\
\hline $57-1,92-94$ & 0.10 & -25.5 & & \\
\hline $69-1,67-68$ & 0.07 & -24.9 & Campanian & Olive green mudstone \\
\hline $72-1,109-111$ & 0.05 & -24.1 & & \\
\hline $74-2,20-22$ & 0.11 & -22.7 & & \\
\hline $78-7,38-43$ & 0.12 & -24.2 & $\begin{array}{l}\text { Coniacian- } \\
\text { Santonian }\end{array}$ & \\
\hline $85-5,92-99$ & 0.13 & -23.6 & & Green claystone \\
\hline $86-4,118-127$ & 0.06 & -23.9 & & Light green claystone \\
\hline $87-1,34-38$ & 0.11 & -24.7 & & \\
\hline $87-1,58-60$ & 21.80 & -27.5 & & Black shale \\
\hline $87-2,148-150$ & 0.11 & -24.6 & & Dark red claystone \\
\hline $87-4,25-26$ & 3.40 & -26.8 & & Black shale \\
\hline $88-1,81-85$ & 0.10 & -25.9 & & Dark red claystone \\
\hline $88-3,117-119$ & 3.38 & -23.7 & & Black shale \\
\hline $91-2,98-102$ & 0.11 & -25.6 & & Dark brown siltstone \\
\hline $93-6,50-52$ & 0.10 & -24.1 & & \\
\hline $93-6,59-63$ & 1.84 & -24.4 & & $\begin{array}{l}\text { Grayey brown silt- } \\
\text { stone }\end{array}$ \\
\hline $94-1,129-139$ & 0.88 & -25.3 & & \\
\hline $96-1,12-17$ & 0.13 & -24.8 & late Albian- & Brown claystone \\
\hline $96-5,43-50$ & 1.03 & -25.9 & Cenomanian & Black shale \\
\hline $96-5,50-56$ & 0.16 & -24.3 & & Green claystone \\
\hline $96, \mathrm{CC}$ & 4.87 & -26.5 & & Black shale \\
\hline $99-3,89-91$ & 0.16 & -24.6 & & $\begin{array}{l}\text { Grayey brown clay- } \\
\text { stone }\end{array}$ \\
\hline $99-5,60-61$ & 0.21 & -24.8 & & Green claystone \\
\hline $99-5,74-75$ & 1.73 & -25.6 & & Grayey black shale \\
\hline $99-5,145-150$ & 2.64 & -26.6 & & Black shale \\
\hline $100-2,147-150$ & 1.33 & -25.3 & & \\
\hline $100-3,50-57$ & 0.22 & -24.0 & & Green claystone \\
\hline $101-3,49-59$ & 0.27 & -23.8 & & \\
\hline $101-4,20-23$ & 8.81 & -26.7 & & Black shale \\
\hline $101-5,140-147$ & 0.15 & -24.3 & & $\begin{array}{l}\text { Dark brown clay- } \\
\text { stone }\end{array}$ \\
\hline $102-2,0-8$ & 17.90 & -26.0 & & Black shale \\
\hline $103-3,64-67$ & 1.18 & -26.3 & & \\
\hline $103-3,67-70$ & 0.27 & -25.0 & & $\begin{array}{l}\text { Light green mud- } \\
\text { stone }\end{array}$ \\
\hline $104-1,124-131$ & 0.65 & -25.0 & & $\begin{array}{l}\text { Dark brown mud- } \\
\text { stone/siltstone }\end{array}$ \\
\hline $104-3,94-96$ & 2.79 & -25.7 & & \\
\hline $104-4,144-148$ & 0.63 & -25.0 & & \\
\hline $105-2,97-99$ & 1.13 & -24.9 & & Black shale \\
\hline $105-2,99-100$ & 5.46 & -26.4 & & \\
\hline $102-2,141-144$ & 4.26 & -25.6 & & \\
\hline $105-3,4-10$ & 0.18 & -23.2 & & Light green mudstone \\
\hline $105-3,141-147$ & 0.08 & -25.3 & & Black shale \\
\hline $105-5,26-29$ & 0.12 & -25.5 & & \\
\hline $105-5,146-150$ & 0.12 & -25.5 & & $\begin{array}{l}\text { Dark brown mud- } \\
\text { stone/siltstone }\end{array}$ \\
\hline $105-6,0-1$ & 0.11 & -24.7 & & \\
\hline $105-6,1-3$ & 0.11 & -24.3 & & Light green mudstone \\
\hline $105, \mathrm{CC}(0-2)$ & 0.12 & -24.7 & & $\begin{array}{l}\text { Dark brown mud- } \\
\text { stone/siltstone }\end{array}$ \\
\hline
\end{tabular}

${ }^{\text {a }}$ Revisions of stratigraphic ages are given in Steinmetz et al., this volume.

green and red claystones have about the same $\delta^{13} \mathrm{C}$ values $(-24.6$ to $-24.7 \%)$, whereas $\delta^{13} \mathrm{C}$ values of black shales are significantly lower, ranging from $-26.8 \%$ to $-27.5 \%$. The black shale in Section $88-3$ shows a remarkably less depleted $\delta^{13} \mathrm{C}$ value than do other black shales.

This difference may result from the amount of lightgreen sediments, relatively enriched in ${ }^{13} \mathrm{C}$, present in the black shale layer. There are many black shale beds with variable thickness $(1-15 \mathrm{~cm})$ in Core 96 . The average $\delta^{13} \mathrm{C}$ value for the black shales is $-26.2 \%$, indicating that the organic carbon in this section is also enriched in ${ }^{12} \mathrm{C}$ compared with that in green or brown claystones, where the average value of $\delta^{13} \mathrm{C}$ is $-24.5 \%$. Sections : $99-3$ through 5 have a range from $-24.6 \%$ to $-26.5 \%$. Apparently, this difference results primarily from variation in the relative amounts of total organic carbon in the black shales and brown or green claystones, where the $\delta^{13} \mathrm{C}$ value becomes smaller with an increase in the content of total organic carbon. A similar trend is observed in the sediments from Cores 100 to 105 . Sections $100-3 ; 101-3$ through 5 ; and 105-3 are richer in ${ }^{13} \mathrm{C}$, indicating a predominant marine origin with a minor terrestrial component.

A medium gray, fine-grained basalt was cored at Site $530(19 \mathrm{~m})$. The basalt is light gray with a thin white altered glassy layer immediately below the mud/claystone. The mud/claystone in the vicinity of the basalt appears to be thermally altered or baked (see site summary). Simoneit et al. $(1978,1981)$ noted that $\delta^{13} \mathrm{C}$ and D values of thermally altered black shales are heavier than those of the unaltered samples, indicating that the lighter isotopes ${ }^{12} \mathrm{C}$ and $\mathrm{H}$ were preferentially lost during the thermal event at Site 368, Cape Verde Basin.

At Site 530, the black shales above the basement, which are intimately associated with the laminated light green to dark brown mud/siltstones, have a range from $-24.9 \%$ to $-26.4 \%$. This is a similar to those of black shales in the upper sections. In addition, the $\delta^{13} \mathrm{C}$ values in the vicinity of the basalts do not exhibit any linear trends resulting from the thermal activity of basalt. From Sections 105-3 to the core catcher, however, the organic carbon contents vary, but are generally lower in the vicinity of the basalt, whereas $\delta^{13} \mathrm{C}$ values of the black shales are slightly higher than those in the upper sections. Thus, only the sediments nearest basalt appear to be affected by thermal stress resulting from basalt intrusion.

Systematic isotopic differences between marine and fresh-water limestones and fossils were shown by various workers. In general, $\delta^{13} \mathrm{C}$ for marine plants ranges from $-8 \%$ to $-17 \%$, whereas for land plants it ranges from $-22 \%$ to $-29 \%$ (Craig, 1953; Clayton and Degens, 1959; Keith et al., 1964; Sackett, 1964; Keith and Parker, 1965; Degens, 1969). All available analyses indicate that the average composition of land and marine plants differs by $8 \%$, with marine plants less enriched in ${ }^{12} \mathrm{C}$, although some exceptions occur in high-latitude areas (Sackett et al., 1965). Similarly, the carbon of nonmarine petroleum is also considerably lower in ${ }^{13} \mathrm{C}$ than is that of petroleum of marine origin (Degens, 1969).

Information regarding carbon isotopes in the black shales is less plentiful. Simoneit (1978a) reported that sapropelitic mudstone from Site 364 (Leg 40) has total extract $\delta^{13} \mathrm{C}=-26.5 \%$ and kerogen $\delta^{13} \mathrm{C}=-27.0 \%$, values typical of land plants. Foresman (1978) also noted that Cretaceous black shales at Site 364 have carbon isotope compositions low in ${ }^{13} \mathrm{C}$, indicating that there has been a sporadic input of terrigenous material to part of the Angola Basin during the Cretaceous times. Similarly, the black shale samples from Site 367 (North Atlantic) have a mixture of marine and terrestrial organic matter and a very terrestrial carbon isotope composition $\left(\delta^{13} \mathrm{C}=-28.9 \%\right.$ ) (Simoneit, 1978).

The carbon isotope compositions at Site 530 apparently reflect the lithological character of sediments. In 
general, the light-olive green mud/claystones range from $-22.7 \%$ to $-25.5 \%$, with an average of $-24.3 \%$; while dark brown-red mud/silt/claystones have an average of $-25.0 \%$, ranging from $-24.1 \%$ to $-25.8 \%$. The black shales are remarkably enriched in lighter ${ }^{12} \mathrm{C}$ compared to those in other lithological facies (Fig. 2). A detailed analysis of one sample also exhibits a similar trend in isotope compositions. For example, carbon isotope compositions in the Core 99 , Sections $3 \sim 5$ vary from $-24.6 \%$ to $-26.6 \%$, reflecting its lithologic type.

The following relationship exists between isotope composition and amount of organic carbon in the sediments (Fig. 3): The sample that contains the highest total organic carbon content shows the greatest depletion in ${ }^{13} \mathrm{C}$, whereas less depleted $\delta^{13} \mathrm{C}$ values are observed in sediments having low total organic carbon contents. Thus, it seems likely that the organic matter in each sediment type has a different origin.

It is possible that the organic carbon-rich layers become anoxic almost immediately after deposition because of the high oxygen demand within the sediments. Reducing conditions may be extended into the underlying red clay and into overlying layers. This would produce a sequence of two red clay (or green clay) layers with a black shale layer "sandwiched" in between (see site summary, this volume). It is likely that the trend in isotope composition mentioned above might partly result from such a process. However, most available evidence suggests that diagenesis within sediments does not result in significant change in the isotope composition of organic carbon (Sackett, 1964; Degens, 1969). Therefore, this variability in carbon isotope composition can be attributed to differences in source materials, suggesting that the black shales did originate primarily from terrestrially derived organic matter, as in the Bay of Biscay, Cape Verde Basin, and Angola Basin, Site 364 (Foresman, 1978; Simoneit, 1978, 1979; Summerhayes, 1981). This thesis is further supported by the presence of large amounts of land plant debris and detrital angular plagioclase in the black shales (Schallreuter, pers. comm.). Moreover, the data for organic carbon isotope

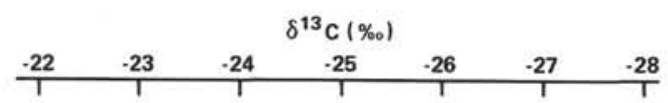

Light-olive green mudstone/claystone

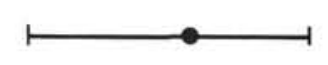

Dark brown-red

mudstone/siltstone/claystone

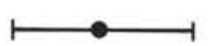

Black shale

Figure 2. Range of organic carbon isotope composition in the Cretaceous sediments from Site 530. (Solid circle represents mean $\delta^{13} \mathrm{C}$ in each sediment type.)

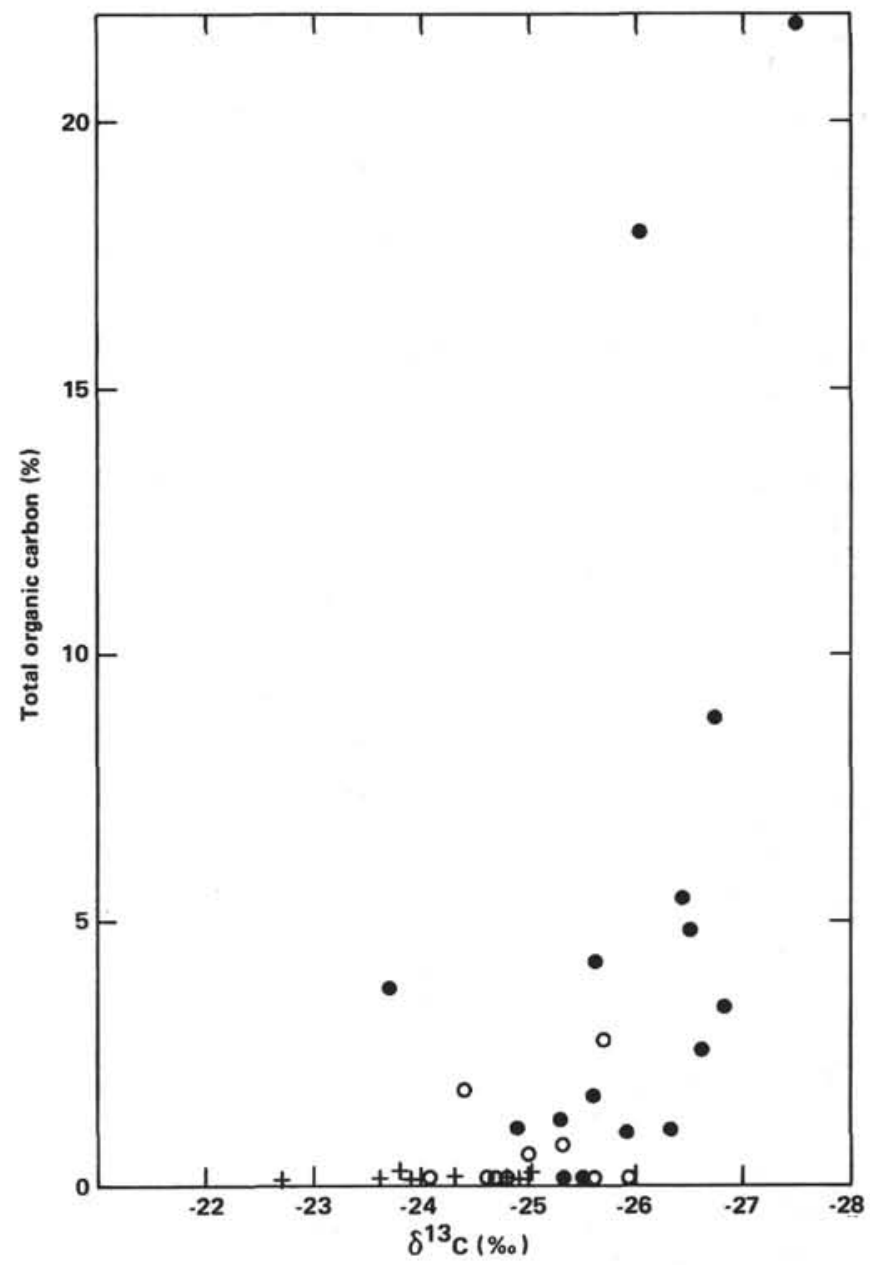

Figure 3. Relationship between total organic carbon content and $\delta^{13} \mathrm{C}$ in Cretaceous sediments from Site 530. (Solid circle represents black shale; open circle represents dark brown-red mudstone/siltstone/claystone; cross represents light-olive green mudstone/claystone.)

composition suggest that a sequence of oxic and anoxic layers was formed by a periodic input of large amounts of land-derived organic matter, which changed layers from oxic to anoxic conditions, rather than by diagenesis within sediments or high productivity of marine organisms by upwelling.

Figure 4 shows the average values of carbon isotope compositions through the Cretaceous times. The Campanian is richer in ${ }^{13} \mathrm{C}$ than are other ages, indicating a larger fraction of marine organic matter. The changes in isotope values with time further suggests that there had been a sporadic introduction of large amounts of terrigenous materials to the Angola Basin during the Cretaceous times, with the exception of the Campanian. This condition is also corroborated by the presence of land plant debris in the sediments, particularly, in the black shales.

\section{CONCLUSIONS}

Cretaceous sediments from the Angola Basin have variable organic carbon isotope compositions, ranging from $-22.7 \%$ to $-27.5 \%$. The $\delta^{13} \mathrm{C}$ values decrease in the 


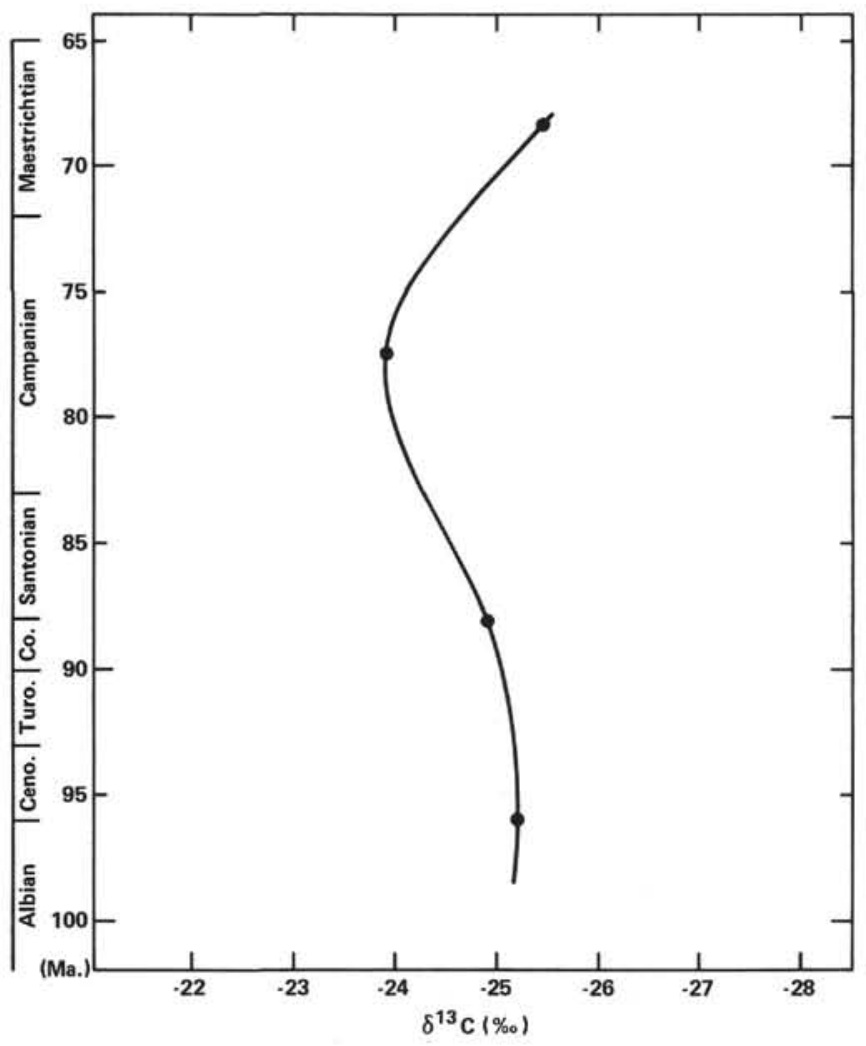

Figure 4. Organic carbon isotopic trend through the Cretaceous times in the Angola Basin.

following order: light-olive mudstone/claystone, dark brown-red mudstone/siltstone/claystone, and black shale.

The average $\delta^{13} \mathrm{C}$ value in the black shales is $-25.9 \%$. The lightest $\delta^{13} \mathrm{C}$ value, $-27.5 \%$, is found in Section 87-1. These values are typical of land plants, indicating an input of large amounts of terrigenous organic materials to this paleoenvironment. The anoxic condition was possibly created by an episodic supply of large amounts of terrestrial organic matter, rather than by diagenesis within sediments or high productivity of marine organisms by upwelling. As a result, the environment in the Angola Basin became anoxic in both the sediment and the water column. This condition is corroborated by the presence of large amounts of land plant debris in the black shales.

Analyses of carbon isotopes indicate an overall influx of organic materials (marine or nonmarine) during the Cretaceous. The Campanian sediments have an average $\delta^{13} \mathrm{C}$ of $-23.9 \%$, suggesting a predominance of marine organisms with small amount of terrigenous component. Except for the sediments above, the late Albian to
Maestrichtian sediments show the lighter $\delta^{13} \mathrm{C}$ values $(\leqq-25 \%)$, suggesting dilution of marine organisms by large amounts of terrigenous organic matter.

Near the basaltic basement, $\delta^{13} \mathrm{C}$ values vary from $-23.2 \%$ to $-26.7 \%$. The $\delta^{13} \mathrm{C}$ values of black shales in the vicinity of basalt are slightly less depleted than are those in the upper sections, whereas total organic carbon content has remained relatively low. These data suggest that the thermal effects resulting from basalt intrusion are very local.

\section{ACKNOWLEDGMENTS}

We would like to thank N. Nasu, H. Kagami, and K. Kobayashi for their helpful advice and constructive reviews of this paper; $\mathrm{K}$. Sugai for making sample holder; and Y. Matsuhisa for his help in operating the mass spectrometer.

\section{REFERENCES}

Clayton, R. N., and Degens, E. T., 1959. Use of carbon isotope analyses of carbonates for differentiating fresh-water and marine sediments. Am. Assoc. Petrol. Geol. Bull., 43:890-897.

Craig, H., 1953. The geochemistry of the stable carbon isotopes. Geochim. Cosmochim. Acta, 3:53-92.

Degens, E. T., 1969. Biogeochemistry of stable carbon isotopes. In Eglinton, G., and Murphy, M. T. J. (Eds.), Organic Geochemistry, Methods and Results: Berlin (Springer-Verlag), pp. 304-329.

Foresman, J. B., 1978. DSDP Leg 40: Continental rise of southwest Africa. In Bolli, H. M., Ryan, W. B. F., et al., Init. Repts. DSDP, 40: Washington (U.S. Govt. Printing Office), 557-567.

Keith, M. L., Anderson, G. M., and Eichler, R., 1964. Carbon and oxygen isotopic composition of mollusk shells from marine and fresh-water environments. Geochim. Cosmochim. Acta, 28: 1757-1786.

Keith, M. L., and Parker, R. H., 1965. Local variation of ${ }^{13} \mathrm{C}$ and ${ }^{18} \mathrm{O}$ content of mollusk shells and the relatively minor temperature effect in marginal marine environments. Mar. Geol., 3:115-129.

Sackett, W. M., 1964. The depositional history and isotopic carbon composition of marine sediments. Mar. Geol., 2:173-185.

, Eckelmann, W. R., Bender, M. L., and Bé, A. W. H., 1965. Temperature dependence of carbon isotope composition in marine plankton and sediments. Science, 148:235-237.

Simoneit, B. R. T., 1978. Leg 41 sediment lipids-Search for eolian organic matter in Recent samples and examination of a black shale. In Lancelot, Y., Seibold, E., et al., Init. Repts. DSDP, 41: Washington (U.S. Govt. Printing Office), 855-858.

1979. Lipid analyses of sediments from Site 364 in the Angola Basin, DSDP Leg 40. In Bolli, H. M., Ryan, W. B. F., et al., Init. Repts. DSDP, Suppl. to Vols. 38, 39, 40, and 41: Washington (U.S. Govt. Printing Office), 659-662.

1981. Thermal alteration of Cretaceous black shale by diabase intrusion in the eastern Atlantic. II. Effects on bitumen and kerogen. Geochim. Cosmochim. Acta, 45:1581-1602.

Simoneit, B. R. T., Brenner, S., Peters, K. E., and Kaplan, I. R., 1978. Thermal alteration of Cretaceous black shale by basaltic intrusion in the eastern Atlantic. Nature, 273:501-504.

Summerhayes, C. P., 1981. Organic facies of middle Cretaceous black shales in deep North Atlantic. Am. Assoc. Petrol. Geol. Bull., 65: 2364-2380.

Date of Initial Receipt: December 3, 1982 